\title{
Spatial and temporal dynamics in genetic diversity in upland rice and late millet (Pennisetum glaucum (L.) R. Br.) in The Gambia
}

\author{
Edwin Nuijten · Rob van Treuren
}

Received: 6 October 2005/ Accepted: 14 May 2006/Published online: 24 January 2007

(C) Springer Science+Business Media B.V. 2007

\begin{abstract}
Ambiguity exists about the level of genetic diversity represented by farmer crop varieties, how it develops over time and how it relates to the diversity comprised by formal varieties. As part of an interdisciplinary technological/sociological study on farmer management of gene flow, upland rice (Oryza sativa L.) and late millet (Pennisetum glaucum (L.) R.Br.) from The Gambia were investigated for morphological and molecular variation. The goal of these analyses was to obtain insight into the level of crop genetic diversity of farmer's materials planted in several case study villages in The Gambia. For both crops, samples were collected from villages and various research institutes. Based on variety names, different rice and millet varieties were expected to be used in different villages. In fact, there was a large overlap in genetic diversity for both crops, masked by the use of synonyms. The considerable similarity in rice genetic diversity between villages most
\end{abstract}

\section{E. Nuijten $(\square)$}

Technology and Agrarian Development group,

Wageningen University, Hollandseweg 1, 6706 KN

Wageningen, The Netherlands

e-mail: edwin.nuijten@wur.nl

R. van Treuren

Centre for Genetic Resources, The Netherlands

Wageningen University and Research Centre, P.O.

Box 16, 6700 AA Wageningen, The Netherlands likely results from the exchange of varieties between farmers. For millet this seems the result of development of varieties from the same gene pool. Some farmer varieties of rice, however, are apparent hybrid forms between the species $O$. sativa and $O$. glaberrima Steud., and farmer varieties in general displayed higher levels of genetic diversity than formal varieties. This indicates that, for rice, genetic diversity develops in farmers' fields and may have potential use in formal breeding programs.

Keywords Genetic diversity Pearl millet (Pennisetum glaucum (L.) R.Br.) · Rice (Oryza sativa L.) - Spatial and temporal dynamics .

The Gambia

\section{Introduction}

In low-input farming systems farmers often use a wide range of crop varieties, to provide harvest security, yield stability and the possibility to adapt to changing ecological conditions (Hardon and De Boef 1993; Teshome et al. 1999). Farmers in these situations adopt modern varieties only to a limited extent, or not at all. The main reason for not adopting modern varieties is that they do not meet farmers' requirements. In recent years, various Participatory Plant Breeding initiatives have been set up to develop varieties to meet 
farmers' requirements better (Almekinders and Elings 2001; Sperling et al. 2001). Some of these programmes aim to collaborate with farmers in very early stages of crop development, with the breeder acting more as a facilitator providing the raw genetic material. It is suggested that farmers maintain high levels of crop diversity through developing new varieties and by matching specific varieties to particular conditions. How much genetic diversity these varieties represent, however, has not often been studied and different processes seem to regulate the amount and development of genetic diversity in crops in lowinput farming systems. Rather than continuing to assume that the obvious morphological diversity of traditional varieties assures a broad genetic base on-farm, diagnostic surveys of genetic variation and genetic distance between varieties are urgently needed (Wood and Lenné 1997).

The focus of this paper is on assessing genetic diversity at crop level (by comparing variety pools across several villages) and not at the individual variety level (i.e. within varieties) for two crops with contrasting breeding systems. Two main processes can be identified regulating genetic diversity in farming systems. As the result of one process farmer varieties look very diverse morphologically, but are actually genetically uniform because of continuous selection on qualitative traits in the same gene pool (Cox and Wood 1999) and because most farmer varieties are derived through genetic recombination of existing farmer varieties (Wood and Lenné 1997). This process leads to a convergence of genetic diversity over time. A second process, however, maintains genetic diversity in the 'local gene pool' through mutation, introgression from wild and weedy relatives, hybridisation between varieties and the introduction of new landraces or formal (i.e. modern) varieties (Almekinders et al. 1994; Almekinders and Elings 2001). It has sometimes been argued that the introduction of formal varieties halts this process in its tracks, and thus reduces genetic diversity in farming systems (Altieri and Merrick 1987; Ceccarelli et al. 1992). Modernisation of agriculture tends to replace large numbers of farmer varieties with small numbers of formal varieties (Cooper et al. 1994). An issue arising is whether formal or farmer varieties represent higher levels of genetic diversity. It is often assumed by plant breeders that formal varieties represent more genetic diversity than farmer varieties since plant breeders have access to world-wide genetic resources, whereas farmers do not (Smith 2000). An example often mentioned is the genetic background of the rice (Oryza sativa L.) variety IR 64, based on 20 varieties (Dalrymple 1986). This leads to the assumption that formal varieties increase genetic diversity in low-input farming systems. However, it is also common practice in breeding programs to continue breeding with a limited number of elite materials, forming a narrow gene pool (Rasmusson and Philips 1997). Consequently, another assumption is that farmer varieties represent much more diversity than formal varieties because the genetic base of formal varieties has been greatly narrowed. If farmer varieties are replaced by formal varieties, genetic diversity in farming systems will be reduced (Chang 2003). It is perhaps worth noting that in the case of the 20 varieties contributing to the make-up of IR 64, four contributed $65 \%$ to its genetic background (cf. Dalrymple 1986). Similarly, in the case of North American soybean (Glycine max L.) 6 ancestors (out of a total of 80) constituted more than half the genetic base of 258 cultivars released between 1947 and 1988 (Witcombe 1999). A fog of contrasting assumptions thus obscures the issue of whether science or traditional agriculture is better at keeping plant genetic resources in play.

A factor complicating any analysis of genetic diversity in traditional farming systems is that different farmers may use the same name for different varieties, or use different names to indicate the same variety. Morphological analysis may be used to analyse genetic diversity, but only visual traits are assessed. To offer the real diagnosis for which Wood and Lenné (1997) have called, we must turn to molecular techniques. Molecular analysis assesses the hidden genetic diversity, complementing morphological analysis. This paper presents data based on morphological and molecular analyses of genetic diversity at village level found in upland rice (Oryza sativa) and pearl millet (Pennisetum glaucum (L.) R.Br.) in The Gambia. In The Gambia, rice and millet are the main staple crops. Moreover, contrasting 
breeding systems-rice being an inbreeder and millet being an outbreeder-allows study of the effect of crop breeding systems on farmer seed systems. As a study site, The Gambia is particularly interesting because both crops are grown by persons from the same residential compounds, allowing a comparison at compound level. In addition, (African) rice and millet are both indigenous to the area, and wild and weedy relatives can be found in farmers' fields.

The data presented in this paper derive from an interdisciplinary technological and sociological study on farmer management of gene flow (both seed and pollen) in low-input farming systems. Morphological and molecular data were used to identify homonyms and synonyms among locally named varieties and to analyse the level of diversity between villages for both crops. This implies understanding which varieties can be found in which villages and analysing the extent to which these varieties are genetically similar. For rice, the data were also used to compare genetic diversity represented by formal and farmer varieties, and to compare older with newer farmer varieties. Such comparisons were not possible for millet because no improved varieties of late millet are used by farmers in The Gambia and because information from farmers did not allow differentiation between new and old farmer varieties of late millet. Because millet is an outbreeder and genetically diverse at the population level, it was also investigated whether seed lots of the same millet variety used at different geographic locations have become differentiated between villages as a result of local adaptation.
Summarising, the primary research objective was to assess the influence of crop breeding system on genetic diversity over time and space by comparing variety pools of several villages in the cases of rice (an inbreeder) and millet (an outbreeder). A secondary research objective was to compare the genetic diversity represented by formal and farmer varieties.

\section{Materials and methods}

Study sites

In the western part of The Gambia four villages (Tujereng, Kitti, Faraba and Janack, situated at intervals of 20 to $30 \mathrm{~km}$ in a line from west to east) were chosen as study sites (Fig. 1). Tujereng was chosen as a primary site because in this village governmental and non governmental organisation (NGO) involvement in variety management was very low, thus enabling a study of traditional farmer variety management. The main criteria for the three other villages were that late millet and upland rice were cultivated and that they were situated more or less equidistant from each other. For millet, three additional villages (Sangajor, Damfakunda and Sanending) were also included in the study to enable a better understanding of the effect of the geographical location (Fig. 1). Damfakunda and Sanending are in the extreme east of The Gambia in Upper River Division.
Fig. 1 Location of the study sites

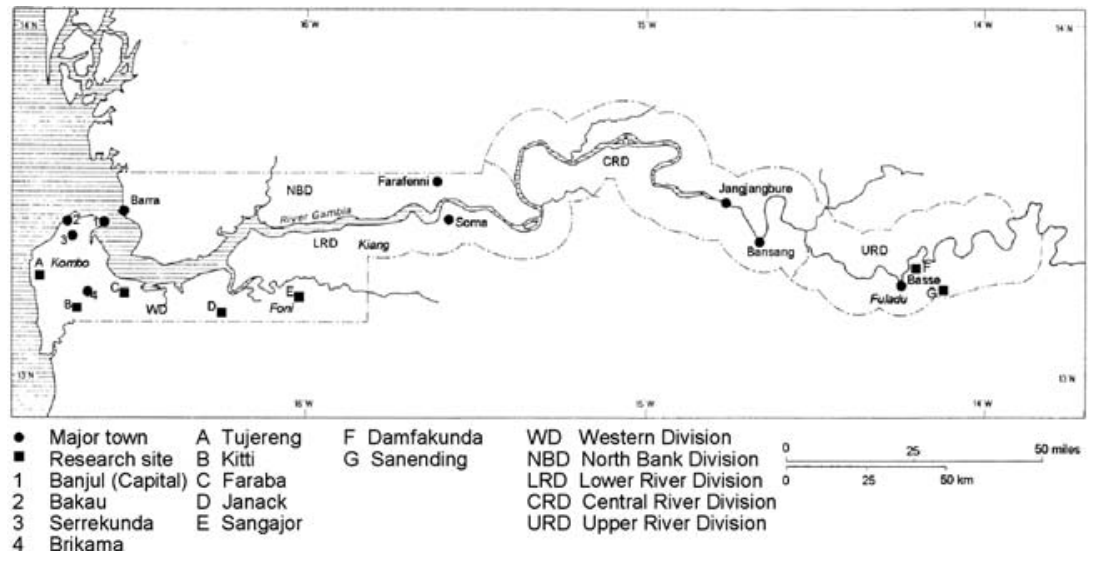


Morphological analysis

\section{Study material}

In this study the term 'farmer varieties' is used to indicate traditional varieties, often denoted as landraces. Based on information from farmers, the farmer varieties were divided in four groups (Table 1). Those for which the time of adoption by farmers was known were denoted as either new or old farmer varieties. The new farmer varieties were adopted by farmers during or after the decrease in rainfall in the early 1970s. A third group consisted of varieties of which the time of adoption was unclear and these are described as 'other farmer varieties'. The fourth group of farmer varieties consists of old farmer varieties not cultivated anymore but still present in farmer varieties as off-types. The term 'formal varieties' is used instead of modern varieties because a number of formal varieties were already developed and released in the 1960s. The formal varieties are divided in two groups. The first includes all formal varieties cultivated by farmers and the second includes those formal varieties recommended for farming, but not adopted by farmers in the study area. For millet, the only terms used are 'farmer varieties' and 'formal varieties', as it was not possible to differentiate these two groups further.

Per rice sample, $0.5 \mathrm{~kg}$ of panicles (about 300 panicles) was taken at random from the harvest as a representative sample of a variety. Based on farmers' descriptions of the morphological identity of varieties, each rice sample was cleaned carefully. As a result, the samples of farmer varieties and formal varieties were morphologically equally uniform. Among the cleaned material, 13 off-types were found that were morphologically different from any of the collected varieties. Nine of these off-types were included in the study, of which four were identified as old farmer varieties not cultivated anymore, one as segregating material and four as unknown material. From the four villages a total of 74 rice samples (both formal and farmer varieties) was obtained. The aim of the sampling was to obtain as many of the upland varieties grown in the four villages as possible (in the event about $85-95 \%$ was collected). The
Table 1 Numbers and groups of rice varieties used for the various analyses a One variety (Mani Suntungo) consisted of a mixture of 2 varieties which were separated for AFLP analysis

b An off-type was separated from the variety Mani Wulendingo at the end of the field trial

\begin{tabular}{|c|c|c|c|c|}
\hline & $\begin{array}{l}\text { Total number } \\
\text { of samples } \\
\text { sown in } \\
\text { the trial }\end{array}$ & $\begin{array}{l}\text { Comparison } \\
\text { between } \\
\text { villages } \\
\text { (\# samples) }\end{array}$ & $\begin{array}{l}\text { Comparison } \\
\text { of farmer and } \\
\text { formal varieties } \\
\text { (\# varieties) }\end{array}$ & $\begin{array}{l}\text { AFLP } \\
\text { analysis } \\
\text { (\# varieties) }\end{array}$ \\
\hline Farmer varieties & 36 & 29 & 20 & 20 \\
\hline New farmer variety & 18 & 13 & 6 & 6 \\
\hline Old farmer variety & 10 & 8 & 9 & 9 \\
\hline Other farmer variety & 8 & 8 & 5 & 5 \\
\hline $\begin{array}{l}\text { Old farmer varieties not } \\
\text { cultivated anymore } \\
\text { found in samples } \\
\text { collected from farmers }\end{array}$ & 5 & - & 4 & 4 \\
\hline Formal varieties & 39 & 16 & 27 & 28 \\
\hline $\begin{array}{l}\text { From institutes, } \\
\text { recommended for } \\
\text { cultivation }\end{array}$ & 20 & - & 16 & 16 \\
\hline From farmers & 19 & 16 & 11 & $12^{\mathrm{a}}$ \\
\hline Unclear status & 7 & 7 & 7 & 7 \\
\hline O. glaberrima & 5 & 4 & 4 & 4 \\
\hline O. barthii & - & - & - & 2 \\
\hline Off-types & 7 & - & - & $8^{\mathrm{b}}$ \\
\hline Reference varieties & & & & 4 \\
\hline $\begin{array}{l}\text { Materials from Jusu } \\
\text { (1999) }\end{array}$ & & & & 6 \\
\hline Total & 99 & 56 & 62 & 83 \\
\hline
\end{tabular}


varieties collected in Tujereng (24 compounds sampled) represented about $95 \%$ of all upland varieties grown in Tujereng, while the varieties collected in Kitti (9 compounds sampled) only represented only about $85 \%$ of all upland varieties grown in Kitti. The percentages for Faraba (12 compounds sampled) and Janack (11 compounds sampled) were between 85 and $95 \%$. The reasons that not all varieties were collected are that (a) a farmer growing a particular variety had not harvested it yet, (b) a farmer was reluctant to give us a sample, (c) the farmer had already threshed the harvest of that variety or (d) we had already obtained several samples from that farmer and did not want to ask for too many. Furthermore, in Kitti we did not meet many farmers in their fields. For varieties of which it was very clear that we already had one or several samples, we stopped collecting that variety: for example, if a farmer mentioned she obtained the seed of a particular variety from a farmer we had interviewed before and from whom we had already obtained a sample. It is important to stress the aim of collecting was to obtain a good range of all varieties grown locally. Samples do not represent proportional genetic diversity within farmers' fields, however.

Based on information from NARI-researchers and literature (Gupta and Toole 1986; FAO 2001), a total of 20 formal varieties was obtained from the National Agricultural Research Institute (NARI), the Centre de coopération Internationale en Recherche Agronomique pour le Développement (CIRAD), the Institute Senegalese de Recherche Agronomique (ISRA) and the Africa Rice Centre (WARDA). The formal varieties included both varieties released in the past and recently developed varieties tested in the village of Tujereng in 1998. Two of the formal varieties are so-called Nerica (New Rice for Africa), derived through interspecific hybridisation between the rice species Oryza sativa and Oryza glaberrima Steud.. Formal varieties were also included in the study to establish which of them are presently grown by farmers. Due to renaming by farmers, this cannot be determined by an inventory of variety names alone. Formal and farmer varieties were all $O$. sativa varieties. In addition, four samples of $O$. glaberrima were included as an outgroup to evaluate differences within $O$. sativa.
For millet, a total number of 17 samples, representing 4 varieties, was collected from 7 villages. In addition, a late millet variety from ISRA, improved through bulk selection, and two late millet varieties from the International Crops Research Institute for the Semi-Arid Tropics (ICRISAT) were included in the study. These were the only improved late millet varieties that could be found.

\section{Lay-out of field trials}

Both rice and millet trials were conducted in farmers' fields in Tujereng under researcher management in 2002. For the rice trial, a forest area was slashed and burned. Compound fertiliser (NPK) was applied at a rate of 25:25:25 kg/ha, followed by ploughing of the trial. Only a single fertiliser treatment was given in order to replicate farmers' practices as much as possible and to avoid excessive lodging of farmer varieties. A completely randomised design with 4 replications was used because the trial was positioned in a farmer's field, which, in combination with a large sample number (99 in total), made the use of a more sophisticated field lay-out impossible. Each plot consisted of 2 rows of $3 \mathrm{~m}$ spaced $30 \mathrm{~cm}$ apart. The distance between plants within rows was approximately $10 \mathrm{~cm}$. Tall and short varieties were sown in separate groups within each replication to avoid shading effects. Different samples with the same panicle morphology were randomised and sown adjacently in groups within each replication in order to establish whether they belonged to the same variety. These groups were randomised within each replication.

The millet trial was located in a field which had been left fallow for 5 years. Prior to ploughing, compound fertiliser (NPK) was applied at a rate of $40: 40: 40 \mathrm{~kg} / \mathrm{ha}$ to ensure good soil fertility. A randomised complete block design with 4 blocks was used to filter field variation, with plots of 6 by $3.5 \mathrm{~m}$. The distance between ridges was $70 \mathrm{~cm}$ and between plants about $80 \mathrm{~cm}$.

\section{Measured traits}

Morphological traits of rice and millet were measured following the guidelines of IRRI (1996) 
and IBPR/ICRISAT (1993) respectively. The measured traits are shown in Tables 2 and 3 for rice and millet, respectively. Because of soil variation in the rice trial, one replication was excluded from measurement. For all rice and millet samples, 6 plants per replication were measured, yielding 18 measurements per sample for rice and 24 for millet.

\section{Statistical analysis}

For both rice and millet, plot averages were used for analyses. For rice, principal component analyses (PCA), using SPSS, were performed to compare genetic diversity between villages, and between farmer and formal varieties. For millet, cluster analysis was performed, based on Euclidean distance measures, using Genstat. Some of the millet samples did not set seed because of pests and diseases, and consequently data on plot yield, 1000 seed-weight and 1000-seed volume were excluded from the analysis. For the quantitative traits of millet, ANOVA and Duncan's multiple comparison test were used to analyse which varieties differed significantly, for which traits.

\section{Molecular analysis}

\section{Study material}

For the molecular analysis of rice, the same varieties used for the morphological comparison between modern and farmer varieties (see above) were used. In addition, some extra materials were studied, including the four off-types found among farmer varieties and of unknown origin (see morphological analysis), two off-types found in the field trial in two varieties, and two samples of $O$. barthii A. Chev. as an extra outgroup next to O. glaberrima (Table 1). In 2003, approximately 20 seeds were sown in a greenhouse from each of 65 accessions of $O$. sativa, four accessions of $O$. glaberrima and two accessions of $O$. barthii. For each accession, equal quantities of leaf material were collected from 10 randomly chosen,
Table 2 Measured characteristics of upland rice

\begin{tabular}{|c|c|}
\hline Characteristics & Scale \\
\hline \multicolumn{2}{|l|}{ Vegetative } \\
\hline Plant height & in $\mathrm{cm}$, from soil surface up to the tip of the tallest panicle \\
\hline Leaf length & leaf below flag leaf, from collar to tip of leaf \\
\hline Leaf width & leaf below flag leaf, widest portion of the leaf \\
\hline Ligule length & $\mathrm{mm}$, from the base of the collar to the tip \\
\hline $\begin{array}{l}\text { Basal sheath } \\
\text { colour }\end{array}$ & at basal portion of the main culm \\
\hline Leaf angle & angle of openness $(1=$ erect, $5=$ horizontal, $9=$ droopy $)$ \\
\hline \multicolumn{2}{|l|}{ Inflorescence } \\
\hline Panicle length & in $\mathrm{cm}$, from panicle base to tip, main panicle \\
\hline Husk colour & $\begin{array}{l}0=\text { straw }, 1=\text { gold and gold furrows on straw background, } \\
2=\text { brown spots on straw, } 3=\text { brown furrows on straw, } 4=\text { brown } \\
\text { (tawny) }, 5=\text { reddish to light purple, } 6=\text { purple spots on straw, } \\
7=\text { purple furrows on straw, } 8=\text { purple } 9=\text { black, } 10=\text { white }\end{array}$ \\
\hline Husk pubescence & $\begin{array}{l}1=\text { glabrous, } 2=\text { hairs on lemma keel, } 3=\text { hairs on upper portion, } \\
4=\text { short hairs, } 5=\text { long hairs (velvety) }\end{array}$ \\
\hline Grain length & $\begin{array}{l}\text { main panicle, in mm, length from base of lowermost sterile lemma to } \\
\text { tip of fertile lemma or palea }\end{array}$ \\
\hline Grain width & main panicle, in $\mathrm{mm}$, measure grain at widest point \\
\hline 100 grain weight & weight of 100 seeds (well-developed) \\
\hline Seed coat colour & $\begin{array}{l}1=\text { white, } 2=\text { light brown, } 3=\text { speckled brown, } 4=\text { brown, } 5=\text { red, } \\
6=\text { variable purple, } 7=\text { purple }\end{array}$ \\
\hline \multicolumn{2}{|l|}{ Agronomic } \\
\hline Culm number & number of culms with heads \\
\hline $50 \%$ flowering & number of days after sowing to $50 \%$ flowering \\
\hline Threshability & $\begin{array}{l}\text { assessed via hand threshing, from } 1 \text { to } 9(1=\text { easy to thresh, } 9 \text { is } \\
\text { difficult to thresh) }\end{array}$ \\
\hline
\end{tabular}


Table 3 Measured characteristics of millet

\begin{tabular}{|c|c|}
\hline Characteristics & Scale \\
\hline \multicolumn{2}{|l|}{ Vegetative } \\
\hline Plant height & in $\mathrm{cm}$, from ground level to tip of spike \\
\hline Leaf length & in $\mathrm{cm}$, leaf on 4 th node below the head \\
\hline Leaf width & in $\mathrm{mm}$, leaf on 4 th node below the head \\
\hline Separation & $\begin{array}{l}\text { in } \mathrm{cm} \text {, distance between two successive leaf blades, } 3^{\text {rd }} \text { and } 5^{\text {th }} \text { leaf } \\
\text { from the top of the main culm, divided by } 2\end{array}$ \\
\hline Stem diameter & in $\mathrm{mm}$, between $3 \mathrm{rd}$ and 4 th node from the top of the main culm \\
\hline \multicolumn{2}{|l|}{ Inflorescence } \\
\hline Spike length & in $\mathrm{cm}$, from base to tip, main spike \\
\hline Spike thickness & in $\mathrm{mm}$, widest portion, main spike \\
\hline Length of bristles & $\begin{array}{l}3=\text { short, bristles below level of the apex of the seed } 5=\text { medium, } \\
\text { bristle between } 0 \text { and } 2 \mathrm{~cm} \text { above the seed } 7=\text { long, bristle longer } \\
\text { than } 2 \mathrm{~cm} \text { above the seed }\end{array}$ \\
\hline Bristle colour & $1=$ green $; 2=\tan$ tips $; 3=$ light red; $4=$ red $; 5=$ purple \\
\hline Spike shape & $1=$ cylindrical, $5=$ candle \\
\hline Seed colour & \% black seeds (assessed before sowing) \\
\hline \multicolumn{2}{|l|}{ Agronomic } \\
\hline Tillering ability & \# culms/plant carrying spikes \\
\hline nr of nodal tillers & $3=$ few $; 5=$ intermediate $;=$ many \\
\hline $50 \%$ flowering & number of days after sowing to $50 \%$ flowering \\
\hline
\end{tabular}

two-week-old seedlings that were combined together into a single sample $(\sim 100 \mathrm{mg})$. In addition to bulked sampling, five individual plants from one of the O. glaberrima accessions ('Mani ba', sample 25) and a black-husked accession of $O$. barthii ('O. barthii black') were separately sampled in order to allow testing of homogeneity of accessions. DNA samples obtained in earlier studies were added as references to the study material. These were DNA samples from the formal rice varieties IR36, IR66, RC10 and RC18 (Bertuso et al. 2005) and DNA samples from six farmer rice varieties from Sierra Leone (van Treuren, unpublished). Of the farmer rice varieties from Sierra Leone, three varieties were described as possible interspecific hybrids between the species $O$. sativa and $O$. glaberrima (Jusu 1999). Two separate leaf samples were also collected from each of two mature plants derived from an apparent interspecific hybrid between $O$. sativa and $O$. glaberrima found in the trial. These samples were included to extend the number of entries with interspecific origin and to allow verification of the reproducibility of AFLP fingerprinting profiles. Tissue samples were collected in $2 \mathrm{ml}$ Eppendorf tubes, immediately frozen in liquid nitrogen and stored at $-80{ }^{\circ} \mathrm{C}$ upon return to the laboratory. DNA isolation basically followed the procedures described by
Fulton et al. (1995). In total, 95 rice DNA samples were used for AFLP fingerprinting.

For millet, approximately 60 seeds from each of 8 accessions were sown in the greenhouse, and about $100 \mathrm{mg}$ of leaf tissue was collected from randomly chosen, two-week-old, individual plants. In addition, a single plant from each of two accessions was sampled twice. These four samples were used in a pre-screening to select suitable AFLP primer combinations to be used for the total sample and to allow reproducibility testing of the AFLP fingerprinting profiles. After tissue collection, experimental procedures and DNA extraction followed those described for the rice samples. DNA was extracted from 24 individual samples per accession, except for seed lot 7 represented, due to poor germination, by 19 individuals.

\section{AFLP fingerprinting}

AFLP analyses basically followed the procedures described by Vos et al. (1995). PCR products radiolabelled with $\mathrm{P}^{33}$ were separated by polyacrylamide gel-electrophoresis. The rice samples were analysed for the EcoRI primer E13 (E-AG) in combination with each of the MseI primers M49 (M-CAG) and M51 (M-CCA). These two primer combinations were found appropriate primer combinations for AFLP analysis in rice in an 
earlier study (Bertuso et al. 2005). For millet, a pre-screening of 4 DNA samples was performed using 18 different primer combinations. EcoRI primers E12 (E-AC) and E13 (E-AG) were tested in combination with each of the MseI primers M49 (M-CAG), M51 (M-CCA), M55 (M-CGA) and M61 (M-CTG), and EcoRI primers E32 (E-AAC) and E38 (E-ACT) were tested in combination with each of the MseI primers M49 (M-CAG), M51 (MCCA), M52 (M-CCC), M54 (M-CCT) and M55 (M-CGA). Based on sufficiently clear and reproducible AFLP polymorphisms, the primer combinations E32/M49 and E32/M54 were selected for AFLP analysis of the total sample of millet.

\section{Data analysis}

AFLP fragments in the range of 50-500 base pairs were scored manually for the presence or absence of bands on the autoradiograms. AFLP fragments that differed in size were assumed to represent different loci, each locus potentially having two alleles, i.e. presence and absence of a band. For rice, a total number of 134 bands were scored of which 92 were found to be polymorphic. For millet, 70 polymorphic bands were observed among the 100 bands scored. To compare the rice samples, Jaccard's similarity coefficients were calculated and a cluster analysis was performed using the UPGMA (unweighted pair-group method, arithmetic average) method. These analyses were performed using the NTSYS-pc software package (Rolf 1993). For millet, genetic relationships between the varieties were calculated using Nei's unbiased estimate of standard genetic distance (Nei 1987) and were represented by a dendrogram using the UPGMA clustering algorithm. These analyses were carried out using the software package TFPGA (Miller 1997). Shannon's information index (Vom Brocke 2001) was used to describe the level of variation based on molecular data between groups of rice varieties and within millet varieties. The more polymorphisms and the more equal the ratio between presence and absence of bands per polymorphism, the higher is the value of the Shannon's information index. The maximum value is 0.69 (if the ratio is 0.5 for all polymorphisms). The formula of Shannon's information index is
$\mathrm{H}=-\sum\left[f_{i} \ln f_{i}+\left(1-f_{i}\right) \ln \left(1-f_{i}\right)\right] / n$

$f_{i}$ is the frequency of the AFLP band at the $i$-th locus in a population and $n$ is the total number of marker loci. Monomorphic markers were not excluded from the data set.

\section{Results}

Homonyms and synonyms

Because farmers often use different names for the same variety, or use the same name to indicate different varieties, it is difficult to determine which varieties are actually grown by farmers based solely on variety names. Morphological and molecular data were therefore used to identify homonyms and synonyms. Farmers do not distinguish between farmer varieties and formal varieties, but choose varieties for their agronomic and utilitarian value (Nuijten unpublished).

\section{Rice}

Based on morphological and molecular comparison, a very different picture emerged on variety use and distribution of rice than when variety names were compared (Table 4). When comparing the total number of identified varieties (38) with the total number of given variety names (49), the percentage of identified varieties was only $80 \%$ of the total number of variety names given by farmers. The number of identified varieties per village was on average $89 \%$ of the number of variety names per village belonging to the samples given by the farmers. This percentage ranged from $73 \%$ to $110 \%$ per village, indicating that variety names can lead to both under- and overestimation of the actual number of varieties cultivated.

Some varieties were grown in more than one village, while other varieties were grown only in a single village. In particular, Tujereng and Janack displayed a relatively large number of 'unique' varieties, while Faraba and Kitti did not. In Table 4 it is also indicated which varieties are formal varieties and which are farmer varieties. This distinction was not clear for 7 varieties subsequently labelled with 'Unclear Status'. In all 
Table 4 Status and farmer names of rice varieties sampled in Tujereng, Kitti, Faraba and Janack

\begin{tabular}{|c|c|c|c|c|c|}
\hline Variety & Status $^{\mathrm{a}}$ & Tujereng & Kitti & Faraba & Janack \\
\hline Kari Saba & FV & $\begin{array}{l}\text { Kari Saba } \\
\text { Mani Wulengo }\end{array}$ & $\begin{array}{l}\text { Barafita } \\
\text { Barafita Wulengo }\end{array}$ & Ablie Mano & Ablie Mano \\
\hline Barafita Koyo & FV & Jokadou Mano & Barafita Koyo & $\begin{array}{l}\text { Ablie Mano } \\
\text { Sanyang Mano }\end{array}$ & $\mathrm{c}$ \\
\hline Kumoi & FV & $\mathrm{c}$ & $\begin{array}{l}\text { Mani Wulengo } \\
\text { Mani Wulendingo } \\
\text { Joko Mano }\end{array}$ & Mani Wulengo & \\
\hline Binta Sambou & FV & $\begin{array}{l}\text { Binta Sambou } \\
\text { Mani Tereyengo } \\
\text { Mani Koyo }\end{array}$ & Tujereng Mano & Mani Koyo & \\
\hline Mani Suntungo & MV & & Suntungo & Mani Suntungo & Bajiran \\
\hline Peking & MV & & & & Peking \\
\hline CCA? (lot 29) & MV & & & & Peking \\
\hline CCA? (lot 31) & MV & & Chinese Mano & & \\
\hline CCA? (lot 33) & MV & & & & Derisa Mano \\
\hline CCA? (lot 34) & MV & & & Peking & \\
\hline CCA? (lot 36) & MV & & $\mathrm{c}$ & Baraso & Kabili \\
\hline Rasi & MV & & Peking & $\begin{array}{l}\text { Baraso } \\
\text { Mani Suntungo } \\
\text { Bolongkong Mano }\end{array}$ & \\
\hline Foni Mano & US & Foni Mano & $\mathrm{c}$ & & \\
\hline Akacha & US & & Akacha & & \\
\hline Teiba & US & & & $\begin{array}{l}\text { Teiba } \\
\text { Mani Koyo }\end{array}$ & \\
\hline Chinese red & US & & & Chinese red & \\
\hline Terfatch & MV & & $\mathrm{c}$ & $\mathrm{c}$ & $\begin{array}{l}\text { Terfatch } \\
\text { Mani Mesengo }\end{array}$ \\
\hline Moti & FV & & & & Kumoi \\
\hline Tensi & FV & & & & Tensi \\
\hline Mani Tima & FV & & & & Mani Tima \\
\hline Tombom Mano & FV & & & & Tombom Mano \\
\hline Kukone & US & & & & Kukone \\
\hline Wesiwes $(\text { Wab ...) })^{\mathrm{b}}$ & MV & & & & Wesiwes \\
\hline Kadi Dabo (Se 302G?) ${ }^{b}$ & MV & & & & Kadi Dabo \\
\hline Bonti & FV & Bonti & & & Bonti \\
\hline M Wulendingo & FV & $\begin{array}{l}\text { Mani Wulendingo } \\
\text { Mani Mesengo }\end{array}$ & & & Indingdingo \\
\hline Kukur & FV & Kukur & & & \\
\hline Muso Noringo & FV & Muso Noringo & & & \\
\hline Sefa Koyo & FV & Sefa Koyo & & & \\
\hline Sefa Fingo & FV & Sefa Fingo & & & \\
\hline Sefa Fingo (red) & FV & Sefa Fingo & & & \\
\hline Sefa Nunfingo & FV & Sefa Nunfingo & & & \\
\hline Sefa Nunfingo (white) & FV & Sefa Nunfingo & & & \\
\hline Bendou & FV & $\begin{array}{l}\text { Bendou } \\
\text { Bendung }\end{array}$ & & & \\
\hline Hombo Wulengo & FV & Hombo Wulengo & & & \\
\hline Mani Mesengo & FV & $\begin{array}{l}\text { Mani Mesengo } \\
\text { Mani Tereyengo }\end{array}$ & & & \\
\hline Sainy Kolly & US & Sainy Kolly & & & \\
\hline Sonna Mano & US & Sonna Mano & & & \\
\hline $\begin{array}{l}\text { Total \# sampled } \\
\text { varieties based } \\
\text { on morphological } \\
\text { data }\end{array}$ & 38 & 18 & 8 & 10 & 16 \\
\hline
\end{tabular}


Table 4 continued

\begin{tabular}{llllll}
\hline Variety & Status $^{\text {a }}$ & Tujereng & Kitti & Faraba & Janack \\
\hline $\begin{array}{l}\text { Total \# sampled } \\
\quad \text { varieties based on variety }\end{array}$ & 49 & 20 & 11 & 10 & 16 \\
$\quad$ names given by farmers & & & & 12 & 11 \\
Total \# of farmers & 56 & 24 & 9 & 13 & 21 \\
Total \# samples & 100 & 49 & 13 & \\
\hline
\end{tabular}

Samples indicated with 'CCA? (lot $\mathrm{xx}$ )' greatly resemble the variety CCA, but are different for one or two traits

${ }^{\mathrm{a}} \mathrm{MV}=$ Formal Variety; FV = Farmer Variety; US = Unclear Status

b Identified as MV, but unclear which MV

${ }^{c}$ Variety is identified in that particular village in 2002 but not sampled in 2000

villages, except Tujereng, both formal and farmer varieties were grown.

\section{Millet}

For millet, the nomenclature in the different villages suggested that within each village several varieties are grown and that there is an overlap in variety use between all villages (Table 5). However, in each village all farmers, or a large majority of the farmers in the case of Faraba, grow the same millet variety. Furthermore, it appeared that the same white millet variety is grown only in the villages of Janack and Kitti, and that in the villages of Tujereng and Faraba two different black varieties are grown. In total, 10 variety names were given by farmers, whereas only three varieties could be recognised, based on the morphological and molecular data.

\section{Comparison between villages}

Rice

A PCA analysis was performed to investigate the level of morphological diversity between the investigated villages. In this analysis no distinction was made between formal and farmer varieties. PCA analysis showed that the vegetative characteristics mostly contributed to the first component and that the reproductive traits mostly contributed to the 2nd component. Graphical representation of the data shows a large similarity in rice morphology between villages, as no clear clustering was observed of varieties according to village (Fig. 2). That the villages of Tujereng and Janack hardly share varieties (Table 4) does not show very clearly in Fig. 2. A line has been added to separate $O$. sativa spp. indica from $O$. sativa spp. japonica, based on the results of the molecular analysis (discussed below). Samples from all four villages were observed in the indica group, whereas in the japonica group only samples from Tujereng and Janack were found. It appeared that almost all old farmer varieties from Tujereng belonged to the japonica group, while most of the new farmer varieties from Tujereng fell within the indica group. Farmers indicated that the new farmer varieties entered Tujereng from 1970 onwards, while the old varieties had been in the village before 1950 . The $O$. glaberrima samples appeared
Table 5 Farmer names of the millet varieties sampled in Tujereng, Kitti, Faraba and Janack. Variety names printed in bold are most often mentioned by farmers

\begin{tabular}{lllll}
\hline Variety & Tujereng & Kitti & Faraba & Janack \\
\hline Black sanyo (from Tujereng) & $\begin{array}{l}\text { sanyo } \\
\text { sanyofingo } \\
\text { sanyotima } \\
\text { nyokoyndingo }\end{array}$ & & \\
Black sanyo (from Faraba) & & $\begin{array}{l}\text { sanyo } \\
\text { majo } \\
\text { komba }\end{array}$ & \\
White sanyo & & $\begin{array}{l}\text { sanyo } \\
\text { majokoyo }\end{array}$ & $\begin{array}{l}\text { sanyo } \\
\text { serengo } \\
\text { boltep }\end{array}$ \\
\hline
\end{tabular}


Fig. 2 Relationship between upland rice varieties collected from 4 villages in The Gambia based on PCA analysis of the morphological data. The line separating the varieties is based on the results of the AFLP analysis, and distinguishes the material belonging to the indica (left side) and japonica (right side) subspecies

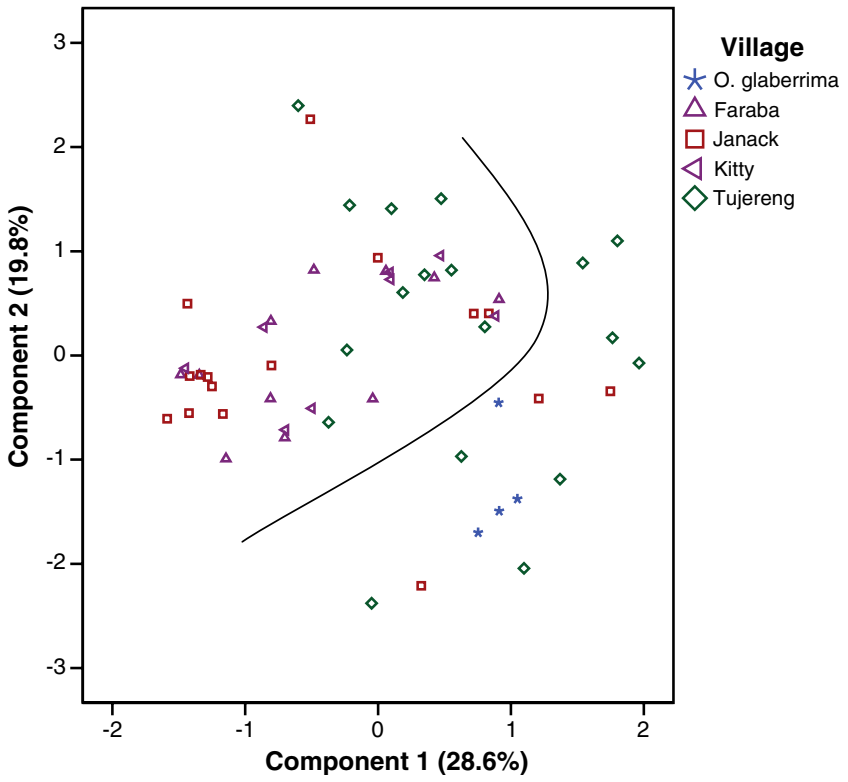

more similar to O. sativa spp. japonica than to $O$. sativa spp. indica.

Four main clusters could be observed, based on the assessment of genetic relationships using AFLP analysis (Fig. 3). All O. glaberrima and $O$. barthii samples grouped together in cluster I, whereas clusters II-IV contained the $O$. sativa samples. All 'WAB' varieties observed in cluster II are known to belong to $O$. sativa spp. japonica (Ghesquière et al. 1997), suggesting that cluster II represents a japonica group. Similarly, IRRI varieties are known to belong to $O$. sativa spp. indica (Dalrymple 1986), suggesting that cluster IV represents an indica group. Because cluster III showed the closest relationship with cluster IV, cluster III was also considered an indica group. Materials cultivated in all four villages were found in clusters III and IV, whereas cluster II was dominated by samples from Tujereng and a few from Janack, but lacked samples from Kitti and Faraba. Cluster II also contained all old farmer varieties except one, whereas cluster III consisted only of 'new' farmer varieties and two interspecific derivatives from Sierra Leone identified by Jusu (1999). These results were in good agreement with those from the morphological analysis. Despite the general good accordance between the data types, some discrepancies were observed. For example, the $O$. sativa farmer varieties 'Sefa Koyo', 'Hombo Wulengo', 'Mani Tima' and 'Kukone', which were morphologically very distinct from each other, showed no differences at the molecular level. In contrast, the farmer varieties 'Moti' and 'Kumoi', which were morphologically very similar, showed a wide genetic distance at the molecular level.

The Shannon information index was used to calculate the level of molecular diversity at village level (Table 6). Diversity values were highest for Tujereng and Janack, because in those villages both $O$. sativa spp. indica and japonica varieties are cultivated, while in the villages Kitti and Faraba only $O$. sativa spp. indica varieties are cultivated. The substantially smaller level of genetic diversity within the japonica group, compared to the indica group, was in contrast to that observed from the morphological data (Fig. 2).

\section{Millet}

Morphological data showed that all samples belonging to the late millet varieties 'black sanyo', 'white sanyo' and 'majo' grouped together in one cluster (Fig. 4). 'Black sanyo' from Faraba clustered closely with 'white sanyo', and the only differences observed between the two varieties were seed colour, 1000-seed weight and bristle 


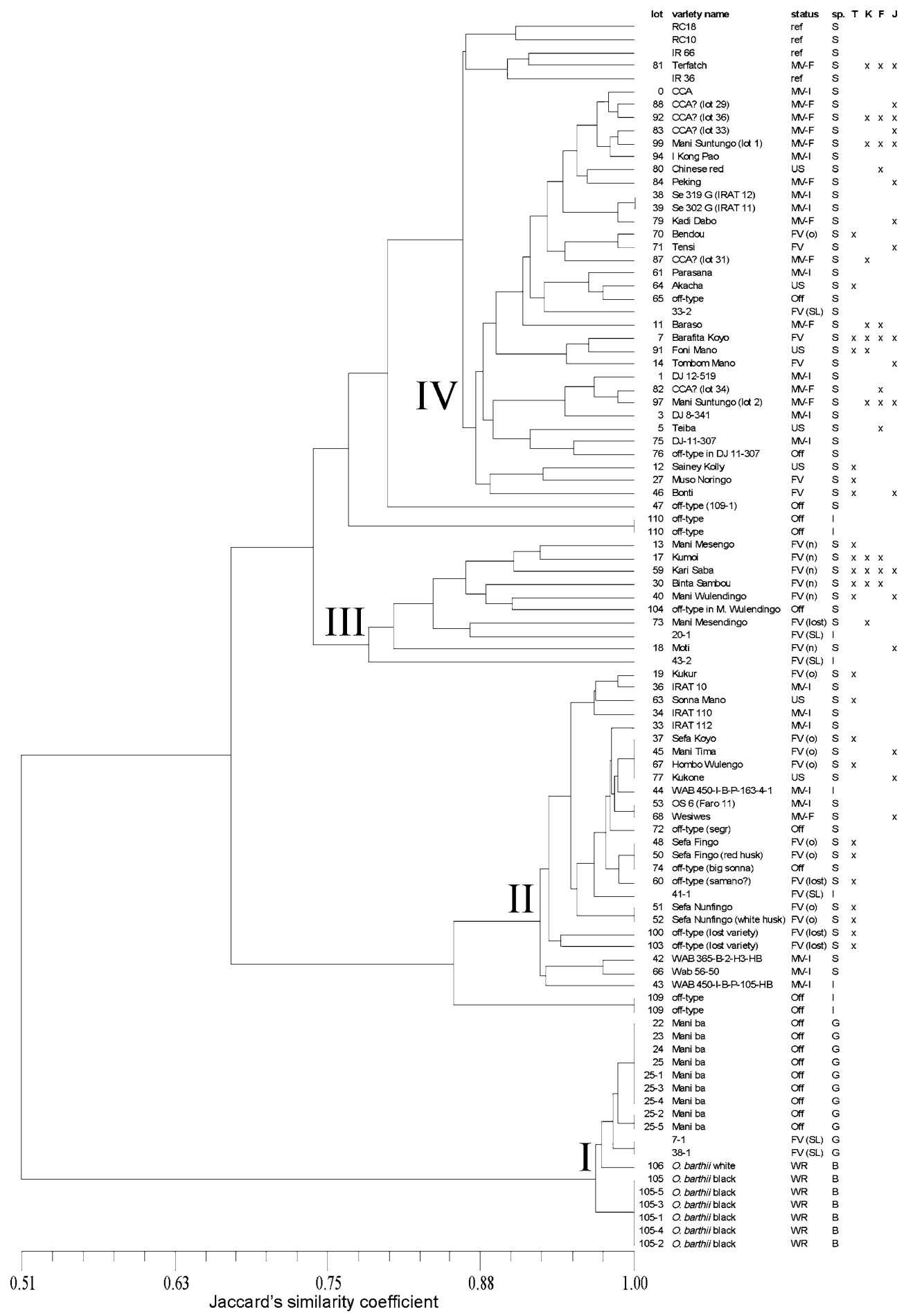

Fig. 3 UPGMA cluster analysis of upland rice varieties based on the AFLP data. MV-I = Formal variety from institute, $\mathrm{MV}-\mathrm{F}=$ Formal variety from farmer, $\mathrm{FV}=$ Farmer variety $(\mathrm{o}=$ old, $\mathrm{n}=$ new $)$, US $=$ Unclear status, Off $=$ Off-type,$\quad \mathrm{WR}=$ Wild rice; $\mathrm{S}=O$. sativa, $\mathrm{G}=$
O. glaberrima, $\mathrm{I}=$ genotype derived from interspecific hybridisation, $\mathrm{B}=\mathrm{O}$. barthii, $\mathrm{SL}=$ Sierra Leone, ref $=$ reference variety, $\mathrm{T}=$ Tujereng, $\mathrm{K}=\mathrm{Kitti}, \mathrm{F}=$ Faraba and $\mathbf{J}=$ Janack 
Table 6 Level of diversity for upland rice in the 4 investigated villages based on molecular data, calculated with the Shannon information index

\begin{tabular}{llllllll}
\hline Shannon information index & Tujereng & $\#$ & Kitti & $\#$ & Faraba & $\#$ & Janack \\
\hline All varieties & $0.32^{\mathrm{a}}$ & 19 & 0.21 & 12 & 0.21 & 12 & $0.28^{\mathrm{a}}$ \\
Indica cluster (III \& IV) & 0.24 & 11 & 0.21 & 12 & 0.21 & 12 & 0.21 \\
Japonica (cluster II) & 0.04 & 8 & - & - & - & - & 0.01 \\
Farmer Varieties & 0.32 & 17 & 0.19 & 4 & 0.19 & 4 & 0.30 \\
Formal Varieties & - & - & 0.11 & 6 & 0.11 & 6 & 0.17 \\
\hline
\end{tabular}

a After 30 at random drawings of 12 samples for Tujereng and Janack, the average values are 0.31 and 0.27 for respectively Tujereng and Janack

colour (data not shown). 'Black sanyo' from Tujereng differed significantly from 'black sanyo' from Faraba for seven traits and from 'white sanyo' for four traits. The clearest difference observed between 'sanyo' (both black and white) and 'majo' was that 'majo' has very short bristles, whereas 'sanyo' has long bristles. According to farmers, two varieties of 'majo' exist, one with long spikes and one with short spikes. However, the clustering of the 'majo' in Fig. 4 is not in accordance with farmers' descriptions of spike size, suggesting that farmers' variety descriptions based on qualitative traits (such as seed colour or presence of bristles) are more suitable to differentiate varieties than quantitative traits such as spike length. Farmers also indicated that two varieties of 'white sanyo' exist, one with long and one with short spikes, but in this study no clear differences in spike length between the 'white sanyo' samples were found.

Using only 'sanyo' and 'majo' samples, the molecular data indicated a higher level of similarity for the millet varieties than observed for the morphological data (Fig. 5). In particular, the two 'black sanyo' varieties from Faraba and Tujereng appeared more closely related based on the AFLP data than appeared from the morphological data. In contrast to the morphological data, the molecular data separated 'majo' from the investigated 'sanyo' varieties.

The level of genetic diversity using the Shannon information index was 0.26 for all samples combined, ranging from 0.21 for the 'majo' sample to 0.26 for one of the Faraba samples (Fig. 5).
Fig. 4 Relatedness between millet varieties based on morphological characterisation; $\mathrm{MV}$ = formal varieties; $\mathrm{FV}=$ farmer varieties

\begin{tabular}{lll} 
MVIFV & origin & variety \\
FV & Kitti & white sanyo \\
FV & Kitti & white sanyo \\
FV & Janack & white sanyo \\
FV & Sangajor & white sanyo \\
MV & ISRA & white sanyo \\
FV & Kitti & white sanyo \\
FV & Sangajor & white sanyo \\
FV & Janack & white sanyo \\
FV & Janack & white sanyo \\
FV & Faraba & black sanyo \\
FV & Faraba & black sanyo \\
FV & Faraba & black sanyo \\
FV & Damphakunda & majo \\
FV & Damphakunda & majo \\
FV & Sanending & majo \\
FV & Sanending & majo \\
FV & Tujereng & black sanyo \\
FV & Tujereng & black sanyo \\
MV & ICRISAT & Leonis \\
MV & ICRISAT & Dauro \\
& \multicolumn{2}{l}{}
\end{tabular}

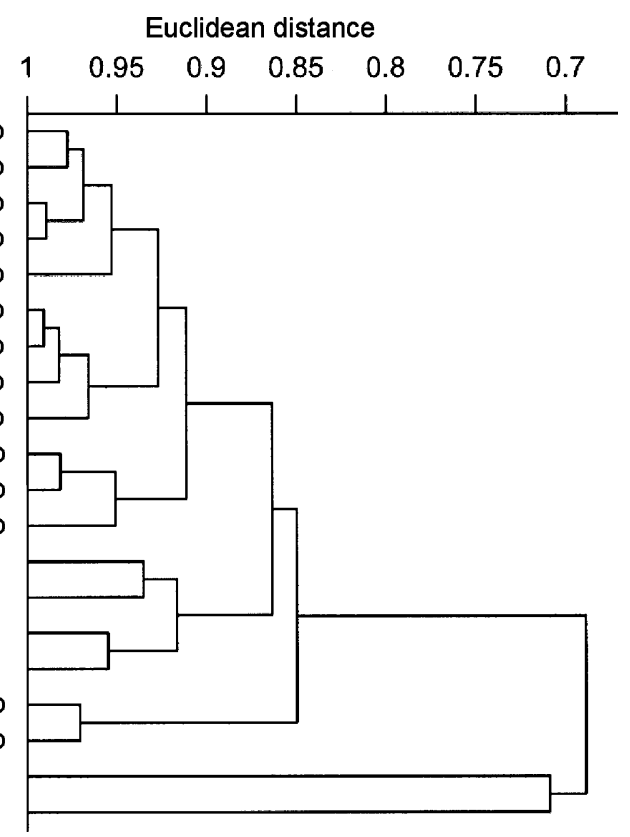




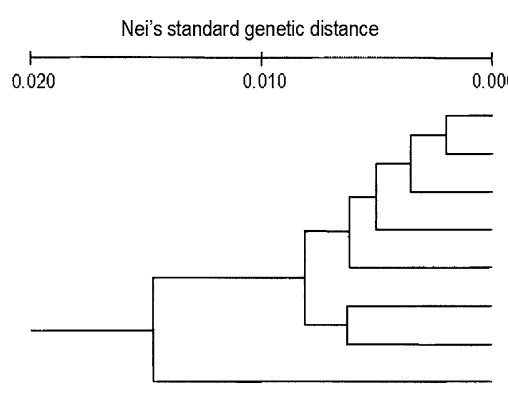

Fig. 5 Relatedness between millet varieties based on AFLP analysis. Variety names are followed by the name of the village in which the material was collected and the

The samples from Faraba and Kitti showed the highest levels of genetic diversity.

\section{Comparison between farmer and formal varieties}

\section{Rice}

In order to investigate the level of morphological similarity between farmer and formal varieties a PCA analysis was performed on a subset of the samples. Traits that contributed most to component 1 were predominantly vegetative traits, while traits that contributed most to component 2 were predominantly inflorescence related traits. Subsequently, differences between varieties were graphically represented by a scatter plot of the first two components of the PCA analysis,

\begin{tabular}{|c|c|c|c|}
\hline variety & village & $\begin{array}{c}\text { Shannon } \\
\text { index }\end{array}$ & $\begin{array}{c}\text { \# poly- } \\
\text { morphisms }\end{array}$ \\
\hline white sanyo & Kitti & 0.26 & 53 \\
\hline white sanyo & Janack & 0.24 & 49 \\
\hline white sanyo & Janack & 0.24 & 51 \\
\hline black sanyo & Faraba & 0.26 & 58 \\
\hline black sanyo & Faraba & 0.24 & 46 \\
\hline black sanyo & Tujereng & 0.23 & 52 \\
\hline black sanyo & Tujereng & 0.22 & 47 \\
\hline majo & Sanending & 0.21 & 47 \\
\hline
\end{tabular}

level of diversity calculated with the Shannon information index and the \# polymorphisms per seed lot

showing a very restricted degree of overlap between formal and farmer varieties (Fig. 6). The formal varieties were mainly clustered in two groups. Group A contains the majority of varieties that were collected from and cultivated by farmers and are referred to as 'MV collected from farmers'. Group B, referred to as 'MV recommended for cultivation', contains almost only varieties that were recommended for rice farming in The Gambia. The formal varieties in cluster A had various origins and most of them were very short, had medium sized grains and were relatively easy to thresh. Cluster B consists of IRAT and WARDA varieties, which were of medium height, with glabrous husks and big seeds that were not easy to thresh. In Fig. 3 all varieties of which the names start with 'DJ' can be found in one sub-cluster of cluster IV. The IRRI-varieties
Fig. 6 Relationship between formal varieties and farmer upland rice varieties of The Gambia based on PCA analysis of the morphological data. Encircled groups of varieties indicate two clusters of formal varieties. The line separating the varieties is based on the results of the AFLP analysis, and distinguishes the material belonging to the indica (left side) and japonica (right side) subspecies

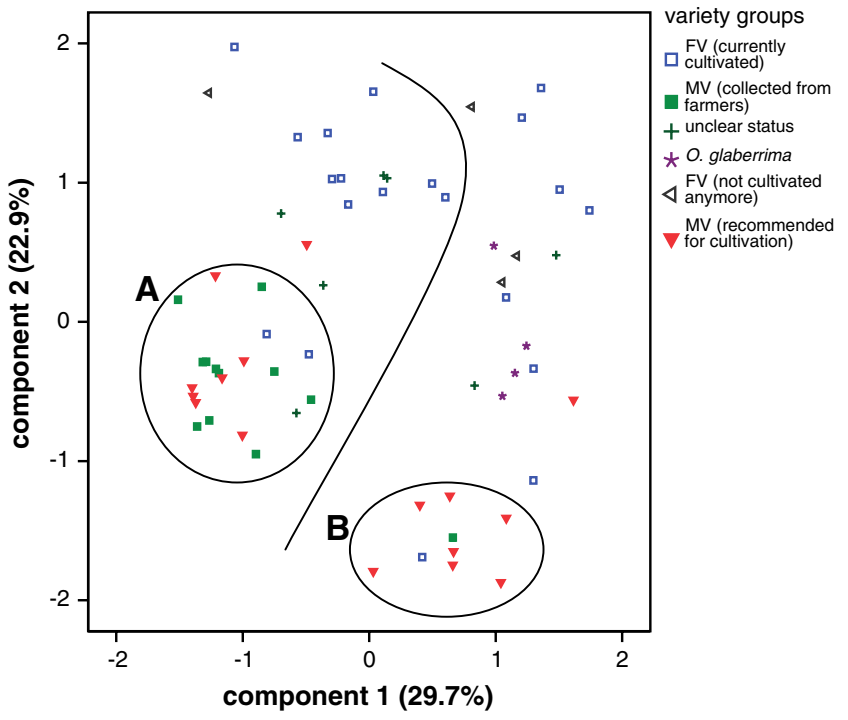


can be found in a sub-cluster separate from the materials collected from farmers. The farmer varieties can also be divided into two groups: those that farmers cultivate nowadays, indicated as 'farmer variety' in Fig. 6, and those not cultivated anymore but still be found as off-types in the field, indicated as 'farmer variety not cultivated anymore'. This establishes that there has been substantial change in genetic make-up of farmer varieties over the past 50 years.

Separation between farmer and formal varieties was also partly observed from the molecular data, as cluster III only consisted of farmer varieties (Fig. 3). However, clusters II and IV showed an irregular grouping of formal and farmer varieties. In contrast to the morphological data (Fig. 6), $O$. glaberrima samples showed a clear distinction from the $O$. sativa samples based on the AFLP data (Fig. 3). Of the 92 polymorphic bands, 29 bands were species-specific. Two plants, forming the progeny of an apparent interspecific hybrid that was found in the trial field, predominantly showed typical $O$. sativa bands but also showed 7 and 8 typical $O$. glaberrima bands. Both plants clustered with $O$. sativa, one in cluster II and the other in between cluster III and IV. Two Nericas, derived from interspecific crosses between $O$. sativa and $O$. glaberrima followed by two backcrosses to $O$. sativa and pollen culture, were found in cluster II. One Nerica (WAB 450-IB-P-105-HB) showed two bands typical for O. glaberrima, while the other Nerica (WAB 450I-B-P-163-4-1) did not show any bands typical for O. glaberrima, suggesting that an accession with
O. glaberrima parentage does not necessarily show this in molecular analysis. Another possibility is that no $O$. glaberrima genes were integrated in the genetic material of the second Nerica because of preferential allele associations (see Pham and Bougerol 1993). An off-type (lot 47) found in a sample collected from a farmer, was found in between cluster III and IV and showed one band typical for O. glaberrima. Three accessions (lot 40, 73 and 104) in cluster III each showed a different band typical for $O$. glaberrima. Furthermore, cluster III showed variation for 3 bands which were either present in all $O$. sativa accessions in clusters II and IV and absent in all $O$. glaberrima accessions in cluster I or vice versa. These findings indicate that some farmer varieties and off-types result from interspecific hybridisation. However, a modern variety (lot 81 ), probably developed at IRRI, shared with lot 73 the band typical for O. glaberrima, which means that some bands are not typical for $O$. glaberrima, but just very rare.

Based on the Shannon index, a higher level of genetic diversity was observed within the group of farmer varieties than in the group of formal varieties (Table 7). Of the various subgroups, the farmer varieties of the japonica subspecies represented the least genetic diversity, while the farmer varieties in cluster III represented the most genetic diversity.

\section{Millet}

The two improved millet varieties from ICRISAT were clearly different from the farmer varieties

Table 7 Level of genetic diversity for various variety groups belonging to the $O$. sativa spp. indica and japonica subspecies based on molecular data, estimated with the Shannon information index and counting of \# polymorphisms

\begin{tabular}{|c|c|c|c|c|}
\hline Cluster & Variety group $^{a}$ & \# samples & $\begin{array}{l}\text { Shannon information } \\
\text { index }\end{array}$ & \# polymorphisms \\
\hline All & MV and FV combined & 48 & 0.31 & 63 \\
\hline \multirow[t]{3}{*}{ All } & MV (all) & 28 & 0.26 & 51 \\
\hline & MV (collected from farmers) & 12 & 0.17 & 43 \\
\hline & $\mathrm{FV}$ & 20 & 0.32 & 56 \\
\hline \multirow[t]{3}{*}{ indica, cluster IV } & MV (all) & 19 & 0.12 & 29 \\
\hline & MV (collected from farmers) & 11 & 0.11 & 26 \\
\hline & $\mathrm{FV}$ & 6 & 0.11 & 18 \\
\hline indica, cluster III & FV & 6 & 0.15 & 28 \\
\hline \multirow[t]{2}{*}{ japonica, cluster II } & MV (all) & 9 & 0.06 & 12 \\
\hline & $\mathrm{FV}$ & 8 & 0.03 & 7 \\
\hline
\end{tabular}

\footnotetext{
${ }^{\mathrm{a}} \mathrm{MV}$ = formal varieties; $\mathrm{FV}$ = farmer varieties
} 
(Fig. 4). It should be noted that the two improved varieties were not well adapted to Gambian conditions. The improved (white) 'sanyo' from ISRA, developed via mass selection, clustered closely with 'white sanyo' samples collected from farmers, indicating a close genetic relationship between improved 'sanyo' with 'white sanyo' collected from farmers.

\section{Discussion}

Homonyms and synonyms

To study crop diversity based on variety names is difficult because of the existence of many homonyms and synonyms. One aspect is that names can lead to both over and underestimation of the number of varieties used by farmers. For millet, the number of names was three times as many as the number of varieties found, based on morphological analysis. Another aspect is that one might over or underestimate the varieties villages share because of the homonyms and synonyms. In a study on Enset (Ensete ventricosum (Welw.) Cheesman) in southwest Ethiopia, it was found that $25 \%$ of the collected clones were duplicates, which was related to different use purposes and the changing of names after exchange between communities (Negash et al. 2002). In a case study on sorghum (Sorghum vulgare L.) in Ethiopia, involving four villages all situated along the main highway between Addis Ababa and Woldeya, it was found that the naming of sorghum varieties was consistent between the villages (Teshome et al. 1997; Tunstall et al. 2001). Of the 48 collected varieties, 35 were grown in at least three of the four villages (Tunstall et al. 2001). This number is much higher than the 7 of 38 rice varieties grown in at least three villages in this study. Hence, the risk of over and underestimating the level of varieties shared among villages differs between areas and crops.

In the 4 villages Tujereng, Kitti, Faraba and Janack 38 upland rice varieties and only 3 late millet varieties were identified. In various studies, it has been shown that in other parts of the world farmers also use a wide range of rice varieties (Richards 1986; Lambert 1985; Dennis 1988). In the case of pearl millet, farmers in Nigeria and Burkina Faso use a wider range of millet varieties compared to The Gambia (Busso et al. 2000; Wilson et al. 1990). This difference in variety use between rice and millet can be explained by the breeding systems of the two crops, rice being a self-pollinator and millet a cross-pollinator, and by the greater complexity of ecological conditions for rice compared to those for millet. Furthermore, Gambian agriculture is gendered: Millet is cultivated by men, while rice is cultivated by women. Women are both cultivators and processors of rice, while men are only cultivators of millet and consequently women have more variety selection criteria than men. Another factor that may play a role in variety management is that women predominantly cultivate rice during the rainy season, whereas men cultivate on average 5 crops during the rainy season (Nuijten, unpublished). In the study area women use on average 3 varieties of rice, while men cultivate 1 variety of millet. Moreover, within a village women use a wide range of rice varieties, while most men use the same millet variety. So, whereas women diversify within a crop, men diversify by growing a range of crops. The reasons why women and men have different diversification strategies will be discussed in a forthcoming paper. Both crops are primarily grown for subsistence. For both crops, farmers mainly depend on their own seed stock and a formal seed sector is almost nonexistent.

\section{Genetic diversity between villages}

Based on the different names given to the various upland rice varieties, one would expect clear differences in genetic diversity between the villages. Morphological and molecular analyses, however, indicated fewer differences in genetic diversity between villages than was expected. The villages of Tujereng and Janack showed greater diversity in rice in the form of $O$. sativa spp. japonica varieties. Traditionally, in both Asian and African rice farming systems most upland varieties belong to $O$. sativa spp. japonica while most lowland varieties belong to O. sativa spp. indica (Glaszmann 1987; de Kochko 1987b). In the past, this also seemed to apply to The Gambia. Nowadays, 
however, many of the varieties commonly cultivated in the uplands belong to the indica subspecies. The reason that japonica varieties were only found in the villages of Tujereng and Janack is that they have typical uplands, whereas Kitti and Faraba do not. It should also be noted that it seems likely many of the 'old' japonica varieties from Tujereng will be lost in the near future, because these old varieties are not suited to the current climatic conditions. Farmers from Tujereng said they had tried most of the formal varieties included in this study, but that for various reasons (too short, too early) they did not adopt them. In 2003, a few farmers in Tujereng started experimenting again with these varieties, partly as a result of poor rainfall in 2002 .

As in the case of rice, farmers give many different names to their millet varieties, which suggests that within each village several millet varieties are grown, whereas in fact often only one variety, or in a few cases two varieties, is grown in each village. In a case study on millet in Niger it was also concluded that differences between varieties do not relate linearly to the names given to these varieties (Busso et al. 2000). Even though morphological analysis indicated that the millet from Tujereng is different from the millet grown in the other three villages, molecular analysis showed that all millet varieties collected from the various villages share the same genetic background. This suggests that selection pressures (both natural and human) do not vary between the villages in the western part of the country, except for seed colour and perhaps seed size. For millet, variety choice seems to be the result of social and cultural factors rather than agro-ecological factors. In Tujereng and Faraba people prefer black millet, whereas in Janack and Kitti, people prefer white millet because of differences in taste. Traditionally, Mandinka people grow black millet and Jola people grow white millet. Interestingly, for rice, no preference was found for red or white seed colour. In Sierra Leone it was found that the Mende prefer red seeded rice types (Richards 1996). In another case study on rice, on the island of Bohol in the Philippines, it was found that rice farmers strongly favour rice varieties with a red pericarp (Bertuso et al., 2005). This underscores the complexity of cultural factors shaping farmer variety selection criteria.

One of the main questions in this study was whether local crop gene pools become genetically more uniform over time. The results on new and old farmer rice varieties from Tujereng show that the new varieties are morphologically less diverse than the old varieties, whereas they are much more diverse than the old varieties at the molecular level. This suggests that the two hypothesised processes outlined in the introduction - genetic diversity being maintained over time in local gene pools and genetic diversity decreasing over time - may alternate. That the old varieties are morphologically very distinct, but very similar at the molecular level is in accordance with the idea that if no new material enters a community and selection takes place within the existing gene pool, phenotypic diversity increases but genetic diversity may actually decrease (Cox and Wood 1999). Some women in Tujereng indicated that some of the old rice varieties were all found in one other old rice variety, called 'Sefa Fingo' (all of which were among the samples).

One important process that leads to genetic diversification is the introduction of new seed types. All new farmer rice varieties in Tujereng arrived just before or after the Sahelian drought (1972-1974), when rainfall was insufficient for the cultivation of the old varieties. When women visit relatives, often over quite long distances, they often bring new rice varieties back to their village. Because the distances they travel are sometimes up to $200 \mathrm{~km}$ or more (often to Senegal and occasionally even to Guinea Bissau), rice seed sources are geographically very dispersed. In this way rice genetic diversity is (unconsciously) increased within a village. That farmers unconsciously maintain genetic diversity by obtaining varieties from distant places is also suggested by Cox and Wood (1999). Furthermore, long distance exchange of varieties increases the chances of the development of genetically distinct, new varieties in the field through cross-pollination. The construction of roads in the rural areas of The Gambia only started after World War II (Haswell 1963). It is difficult to indicate when exactly this resulted in improved transport facilities, but it seems likely that, from the 1960 onwards, improved 
infrastructure helped women to travel more frequently and over larger distances, resulting in more frequent exchange of rice genetic diversity.

This would mean that after 1970 a period of rice genetic diversification started and possibly still continues, while the period prior to 1970 might be considered an era of genetic homogenisation. The implication is that rice genetic homogenisation happens during periods with relatively stable agro-ecological conditions, while genetic diversification is a likely product of periods of changing agro-ecological conditions. During periods of stability it is less necessary for farmers to search for rice varieties, while in periods of change farmers need to travel and look for better adapted varieties.

There is also another factor affecting rice genetic diversity in this case study. It is likely that the cultivation of $O$. sativa spp. japonica and spp. indica varieties in the same field, or in adjacent fields, promoted the emergence of new genetic diversity through inter-subspecific crosses. Both subspecies represent different rice genetic diversity because of a reproductive isolation barrier (see Oka 1988). This might also have contributed to the fact that new rice farmer varieties represent more genetic diversity than the old rice farmer varieties.

For millet, most farmers reported they hardly see any new genotypes in their fields. Because of the large genetic variation within millet varieties and continuous cross-pollination, chances that completely new, distinct genotypes which maintain their distinctiveness in following generations when selected by farmers will emerge in farmer fields are very small. Likely, new stable but not very distinct phenotypes will go unnoticed in the field and will be 'submerged' in the wide phenotypic diversity in the field. For millet, the only chance for noticeable variation to appear would be when genetically distinct varieties are grown side by side. The results of this study indicated, however, that all late millet varieties grown in The Gambia are genetically similar. This means that farmer exchange of different millet varieties over long distances would be unlikely to have a clear, positive effect on genetic diversity. So, whereas for rice, an inbreeding crop, bringing in varieties from distant places might be crucial to the maintenance of genetic diversity in a gene pool, this does not seem to be necessary for millet, an outbreeding crop. It is likely that the higher the rate cross-pollination in a crop, the less liable is genetic diversity to fluctuate at gene pool or crop level. Through variety choices farmers have little influence on crop genetic diversity in millet, while they can have such an impact on rice. Whereas for millet, the majority of crop genetic diversity can be found within varieties, for rice, most crop genetic diversity is found between varieties. This difference is very much related to the different breeding systems of the two crops and it seems likely the inverse relation between the rate of cross-pollination and the fluctuation of genetic diversity in gene pools will be true for other inand out-breeding crops. A study on maize (Zea mays L., an outbreeder) in Mexico indicated little differentiation between populations (Pressoir and Berthaud 2004), while studies on wheat (Triticum aestivum L., an inbreeder) in Jordan and barley (Hordeum vulgare L., also an inbreeder) in Syria and Jordan indicated wide differentiation between landraces (Jaradat 1991; Weltzien 1989).

Farmer and formal varieties

The other main question was whether the introduction of formal varieties increases or reduces genetic diversity in farming systems. The results on rice indicated that the formal varieties represent less genetic diversity than the farmer varieties, a finding in agreement with Chang (2003). However, because formal varieties represent different genetic diversity than farmer varieties, and farmers only partially replace farmer varieties with formal varieties, total genetic diversity increases, which is in line with other studies on rice and millet (Dennis 1987, Vom Brocke et al. 2002). It should be noted, however, that it is likely that the genetic diversity represented by farmer varieties changes over time, and that if this study had been conducted 40 years ago (before the Sahelian drought), the differences in genetic diversity between formal and farmer rice varieties might have been less marked.

It is worth noting, further, that the large genetic diversity represented by the new farmer varieties in cluster III in Fig. 4 is the result of inter-subspecific or interspecific crosses. These 
varieties cluster together with some of the materials that were identified by Jusu (1999) as derivatives of interspecific hybrids based on morphological analysis. Further, molecular analysis showed that two plants formed the progeny of an interspecific cross between $O$. sativa and $O$. glaberrima. An iso-enzyme study on West African rice also revealed intermediate genotypes, which were attributed to inter-subspecific or interspecific crosses (de Kochko 1987a). However, in the future, chances of interspecific hybridisation in Gambian rice fields may reduce and, hence, the chances of the development of genetically unique materials will decrease. Among the reasons the younger generation does not nowadays grow $O$. glaberrima are that it is not drought tolerant and it is difficult to pound.

Although no formal late millet varieties are grown in The Gambia, and those from ICRISAT are not adapted to Gambian conditions, the morphological data suggest that genetic diversity will increase significantly, if suitable, genetically different, formal late millet varieties are introduced. In Rajasthan, India, it was shown that introgression of improved millet varieties into farmer millet varieties can also lead to a higher level of diversity within varieties (Vom Brocke et al. 2002). This strategy to improve farmer varieties applies more to cross-pollinating crops than to self-pollinating crops. In a study on rice on the island of Bohol in the Philippines it was found that farmers developed new rice varieties on the basis of modern varieties (Bertuso et al. 2005).

When the various formal rice varieties are compared with each other, both morphological and molecular data indicated that varieties developed at the same institute resemble each other, but that there are large differences between varieties developed at different institutes. This suggests that the best way to ensure genetic diversity in formal rice varieties is to test and distribute varieties from breeding programs from different institutes. This parallels farmers maintaining genetic diversity by bringing varieties from different places. At the moment, however, most, if not all, formal material tested and distributed to farmers in The Gambia comes from one institute, WARDA. If this continues in the future, it might have a negative impact on genetic diversity in farmers' fields. Because new farmer rice varieties show large genetic distances, these varieties might carry potentially valuable traits useful for formal rice breeding. Most of the polymorphisms present in farmer rice varieties, but not in formal rice varieties, were found in this group of new farmer rice varieties. This then would also mean that it would be beneficial for breeders to visit farmers every 10 years or so to collect rice germplasm from farmer varieties. This applies less to crosspollinating crops like millet. Since diversity represented by farmer varieties is generally underexploited in breeding programs (Hawtin et al. 1997)—e.g. breeding programs are often based on a limited number of landraces (see Dalrymple 1986; Chang 2003; Rasmusson and Philips 1997; Voss 1992; Witcombe 1999) — a change in breeding practices will be required to ensure the utilisation of this diversity. Such genetic resources might be particularly useful in breeding programs aimed at marginal low-input farming systems.

Acknowledgements This research was financially supported by NWO-WOTRO grant W89-124. The authors thank the National Agricultural Research Institute of The Gambia, the field assistants and all collaborating farmers (particularly those from Tujereng) for their support. The authors want to thank Paul Richards, Conny Almekinders and two anonymous reviewers for their comments on the manuscript.

\section{References}

Almekinders CJM, Elings A (2001) Collaboration of farmers and breeders: participatory crop improvement in perspective. Euphytica 122:425-438

Almekinders CJM, Louwaars NP, De Bruijn GH (1994) Local seed systems and their importance for an improved seed supply in developing countries. Euphytica 78:207-216

Altieri MA, Merrick LC (1987) In situ conservation of crop genetic resources through maintenance of traditional farming systems. Econ Bot 41:86-96

Bertuso AR, Van Treuren R, Van Eeuwijk FA, Visser L (2005) Characterisation of red rice (Oryza sativa) varieties developed under on-farm dynamic management on Bohol, Philippines. Plant Genet Resour Newslett 142:1-5

Busso CS, Devos KM, Ross G, Mortimore M, Adams WM, Ambrose MJ, Alldrick S, Gale MD (2000) Genetic diversity within and among landraces of pearl millet (Pennisetum glaucum) under farmer management in West Africa. Genet Resour Crop Evol 47:561-568 
Ceccarelli S, Valkoun J, Erskine W, Weigand S, Miller R, Van Leur JAG (1992) Plant genetic resources and plant improvement as tools to develop sustainable agriculture. Exp Agri 28:89-98

Chang T-T (2003) Origin, domestication and diversification. In: Smith CW, Dilday RH (eds) Rice, origin, history, technology and production, John Wiley and Sons, Inc. Hoboken, New Jersey, pp 3-25

Cooper D, Engels J, Frison E (1994) A multilateral system for plant genetic resources: imperatives, achievements and challenges, Issues in Genetic Resources 2, p 42

Cox TS, Wood D (1999) The nature and role of crop biodiversity. In: Wood D, Lenné JM (eds) Agrobiodiversity: characterization, utilization and management. CABI Publishing, Oxon, pp 35-57

Dalrymple DG (1986) Development and spread of highyielding rice varieties in developing countries. Agency for International Development, Washington

de Kochko A (1987a) A classification of traditional rice varieties (Oryza sativa L.) from Africa using isozymic variability. Evol Trends Plants 1:105-110

de Kochko A (1987b) Isozymic variability of traditional rice (Oryza sativa L.) in Africa. Theor Appl Genet 73:675-682

Dennis JV (1988) Farmer management of rice variety diversity in Northern Thailand. PhD-thesis, Cornell University

FAO (2001) World's planted rice varieties: Gambia. FAO website visited April 2001:http://www.fao.org/waicent/ faoinfo/agricult/agp/agpc/doc/riceinfo/plantvar/gamvar. htm

Fulton TM, Chunwongse J, Tanksley SD (1995) Microprep protocol for extraction of DNA from tomato and other herbaceous plants. Plant Mol Biol Reporter 13:207-209

Ghesquière, A, Séquier, J, Second, G, Lorieux, M (1997) First steps towards a rational use of African rice, Oryza glaberrima, in rice breeding through a 'contig line' concept. Euphytica 96:31-39

Glaszmann JC (1987) Isozymes and classification of Asian rice varieties. Theor Appl Genet 74:21-30

Gupta PC, Toole JCO (1986) Upland rice: a global perspective. IRRI, Los Banos, Philippines

Hardon JJ, De Boef W (1993) Linking farmers and breeders in local crop development. In: De Boef W, Amanor K, Wellard K (eds) Cultivating knowledge: genetic diversity, farmer experimentation and crop research. Intermediate Technology Publications, London, pp 64-71

Haswell MR (1963) The changing pattern of economic activity in a Gambian village. Overseas Research Publication, London, Department of Technical Co-operation, p 109

Hawtin G, Iwanaga M, Hodgkin T (1997) Genetic resources in breeding for adaptation. In: Tigerstedt PMA (ed) Adaptation in plant breeding. Kluwer, Amsterdam, pp 277-288

IBPGR/ICRISAT (1993) Descriptors for pearl millet (Pennisetum glaucum (L.) R. Br.). IBPGR/ICRISAT, Rome

IRRI (1996) Standard evaluation system for rice. International Rice Research Institute, Manila
Jaradat AA (1991) Phenotypic divergence for morphological and yield-related traits among landrace genotypes of durum wheat from Jordan. Euphytica 52:155-164

Jusu MS (1999) Management of genetic variability in rice (Oryza sativa L. and O. glaberrima Steud.) by breeders and farmers in Sierra Leone. PhD-thesis, Wageningen University

Lambert DH (1985) Swamp rice farming, the indigenous Pahang Malay agricultural system. Westview Press, London

Miller MP (1997) Tools for population genetic analyses (TFPGA) 1.3:Windows program for the analysis of allozym and molecular population genetic data: Computer software distributed by author

Negash A, Tsegaye A, Van Treuren R, Visser B (2002) AFLP analysis of enset clonal diversity in South and Soutwestern Ethiopia for conservation. Crop Sci 42:1105-1111

Nei M (1987) Molecular evolutionary genetics. Columbia University Press, New York

Oka HI (1988) Origin of cultivated rice. Elsevier, Tokyo

Pham JL, Bougerol B (1993) Abnormal segregations in crosses between two cultivated rice species. Heredity 70:466-471

Pressoir G, Berthaud J (2004) Population structure and strong divergent selection shape phenotypic diversification in maize landraces. Heredity 92:95-101

Rasmusson DC, Philips RL (1997) Plant breeding progress and genetic diversity from de novo variation and elevated epistatis. Crop Sci 37:303-310

Richards P (1986) Coping with Hunger: hazard and experiment in an African rice-farming system. Allen \& Unwin, London

Richards P (1996) Agrarian creolization: the ethnobiology, history, culture and politics of West African rice. In: Ellen R, Fukui K (eds) Redefining nature: ecology, culture and domestication. Berg, Oxford, pp 291-318

Rolf FJ (1993) NTSYS-pc numerical taxonomy and multivariate analysis system, Version 1.8. Exeter Software. Setauket, New York

Smith S (2000) Perspectives on diversity from an international commercial plant breeding organization. In: Almekinders CJM, De Boef W (eds), Encouraging diversity. Intermediate technology publications, London

Sperling L, Ashby JA, Smith ME, Weltzien E, McGuire S (2001) A framework for analyzing participatory plant breeding approaches and results. Euphytica 122:439-450

Teshome A, Baum BR, Fahrig L, Torrance JK, Lambert JD (1997) Sorghum landrace variation and classification in north Shewa and south Welo, Ethiopia. Euphytica 97:255-263

Teshome A, Fahrig L, Torrance JK, Lambert JD, Arnason TJ, Baum BR (1999) Maintenance of sorghum (Sorghum bicolor, Poaceae) landrace diversity by farmers' selection in Ethiopia. Econ Bot 53:79-88

Tunstall V, Teshome A, Torrance JK (2001) Distribution, abundance and risk of loss of sorghum landraces in four communities in North Shewa and South Welo, Ethiopia. Genet Resour Crop Evol 48:131-142 
Vom Brocke K (2001) Effects of farmers' seed management on performance, adaptation and genetic diversity of pearl millet (Pennisetum glaucum (L. R.Br.) populations in Rajasthan, India. PhD-thesis, Universität Hohenheim

Vom Brocke K, Presterl T, Christinck A, Weltzien E, Geiger HH (2002) Farmers' seed management practices open up new base populations for pearl millet breeding in a semi-arid zone of India. Plant Breed 121:39-45

Vos P, Hogers R, Bleeker M, Reijans M, van de Lee T, Hornes M, Frijters A, Pot J, Peleman J, Kuiper M, Zabeau M (1995) AFLP: a new technique for DNA fingerprinting. Nucleic Acids Res 23:4407-4414

Voss J (1992) Conserving and increasing on-farm genetic diversity: farmer management of varietal bean mixtures in central Africa. In: Moock JL, Rhoades RE (eds) Diversity, farmer knowledge, and sustainability. Cornell University Press, Ithaca, pp 34-51

Weltzien E (1989) Differentiation among barley landrace populations from the Near East. Euphytica 43:29-39

Wilson JP, Burton GW, Zongo JD, Dicko IO (1990) Diversity among pearl millet landraces collected in central Burkina Faso. Crop Sci 30:40-43

Witcombe JR (1999) Does plant breeding lead to a loss of genetic diversity?. In: Wood D, Lenné JM (eds) Agrobiodiversity: characterization, utilization and management. CABI Publishing, Oxon, pp 245-272

Wood D, Lenné JM (1997) The conservation of agrobiodiversity on-farm: questioning the emerging paradigm. Biodiversity and conservation 6:109-129 